\title{
ЗАГАЛЬНИЙ СТАН ДОТРИМАННЯ ПРАВ УВ'ЯЗНЕНИХ В УКРАЇНІ ТА СТАН ДОТРИМАННЯ ПРАВ УВ'ЯЗНЕНИХ НА ТИМЧАСОВО ОКУПОВАНИХ ТЕРИТОРІЯХ ДОНЕЦЬКОЇ ТА ЛУГАНСЬКОЇ ОБЛАСТЕЙ
}

Пенітенціарна система нашої держави покликана ресоціалізувати та реабілітувати ув'язнених осіб, мотивувати людину до змін і підготувати іï до законослухняного життя на волі. Саме тому в цих питаннях держава є важливим помічником засудженому, створюючи необхідні умови для ресоціалізації та реабілітації, а також забезпечуючи дотримання його прав під час ув'язнення.

Як свідчать дослідження вітчизняних науковців, умови утримання в'язнів постійно гуманізуються по всьому світу, створюються такі умови для ув'язнених, за яких вони відбувають покарання доволі комфортно, будучи наділеними більшістю благ, доступних громадянам на волі. Прикладами особливих умов для ув'язнених є якісний ремонт приміщення установ відбування покарань, магазини, спортзали, нові меблі, телебачення, можливості для навчання і творчості та інші умови, які сприяють ресоціалізації ув'язнених.

В Україні подібні умови здебільшого відсутні, при цьому ув'язненим можуть не надаватись навіть ті гарантії, які законодавець закріпив у положеннях чинного кримінально-виконавчого законодавства, також поширеними є різноманітні порушення прав ув'язнених під час відбування ними покарання. Все зазначене ще більше актуалізується у зв'язку із тимчасовою окупацією окремих територій Донецької та Луганської областей, адже, як нами встановлено у цій роботі, стан дотримання прав ув'язнених під контролем окупаційної адміністрації є значно гіршим та складнішим. Як наслідок, засуджені, що відбувають покарання в місцях позбавлення волі, не отримують альтернативу своєму минулому життю та не виправляються. Саме тому з огляду на вищенаведене аналіз загального стану дотримання прав ув'язнених в Україні та стану дотримання прав ув'язнених на тимчасово окупованих територіях Донецької та Луганської областей є важливим для нашого дослідження.

Правам засуджених у своїх роботах приділяли увагу такі дослідники, як: О.П. Букалов, Д.Л. Денисенко, О.М. Джужа, С.Ю. Захаров, В.В. Карелін, О.С. Коробка, М.І. Лисенко, О.В. Лисодєд, Н.М. Мельник, В.О. Новіков, М.В. Романов, Г.П. Середа, В.М. Янко. Але разом із тим комплексні наукові дослідження, присвячені стану дотримання прав ув'язнених на тимчасово окупованих територіях Донецької та Луганської областей, натепер відсутні, а наявні праці мають переважно доповідальний характер.
Так, у 148 установах кримінально-виконавчої системи України, які контролюються українською владою, тобто без установ Криму та окупованої частини Донецької та Луганської областей, згідно 3 даними «Донецького Меморіалу», Адміністрацією кримінально-виконавчої служби України станом на 01.01.2019 року трималося 55078 осіб (станом на 01.01.2018 року - 57100 осіб), при цьому за рік чисельність осіб у місцях позбавлення волі зменшилась на 2022 особи (3299 осіб) [1]. Наведені дані відображають у цілому величезну кількість засуджених осіб, адже на 100 тисяч населення нашої держави припадає приблизно півтори сотні засуджених осіб. Також така кількість осіб, які відбувають покарання, $є$ показником того, наскільки проблемно натепер забезпечити дотримання прав кожного з них. Наявність великої кількості осіб, які відбувають покарання шляхом позбавлення волі, $\epsilon$ однією з передумов наявності тих проблем, які нині є характерними для цієї сфери. Кожна з проблем потребує детального розгляду в рамках цієї роботи та формулювання пропозицій щодо їх вирішення.

Так, автори доповіді «Дотримання прав ув'язнених в Україні-2016» звертають увагу на те, що на загальний стан дотримання прав ув'язнених суттєво впливає сфера надання медичних послуг, яка визначається як «складна та проблемна». Незважаючи на те, що дані, визначені у цій праці, не $€$ найсвіжішими, як зазначають автори, відзначені ними проблеми були актуальними і в аналогічних доповідях від 2006 до 2015 років, а ті заходи, які вживаються для поліпшення ситуації, не є достатніми для того, щоб вирішити наявні проблеми. Зокрема, у 2016 році було зафіксовано високий рівень смертності серед ув'язнених: померло 523 особи, в тому числі 103 особи в СІЗО. Цей абсолютний показник є меншим, аніж у 2011-2014 роках, проте у розрахунку на 1 тисячу ув'язнених померло більше, ніж у попередні роки, крім 2014. Цей рівень значно більший рівня 2009-2010 та попередніх років $(8,66$ особи на 1 тисячу ув'язнених, тоді, як за даними Ради Європи, середньоєвропейський показник становить у середньому 2,8 ). При цьому причини смертності є різноманітними - відзначається і висока кількість самогубств (60 випадків у 2016 та 49 випадків у 2015 році), і захворювань (наприклад, близько 30 хворих на туберкульоз на 1 тисячу ув'язнених). Окрім того, залишаються невирішеними численні труднощі в'язнів-інвалідів, які мають проблеми із забезпеченням протезами та із залученням їх до праці. 
Станом на 1 січня 2017 року в установах виконання покарань утримувалося 1255 осіб, які мають інвалідність. При цьому їхні проблеми не досліджуються, не обговорюються та фактично залишаються поза увагою [2, с. 10-11]. Зазначені дані свідчать про те, що проблема медичних послуг справді є актуальною для ув'язнених в Україні. Статистичні дані свідчать про високий у цілому рівень захворюваності та смертності серед засуджених. 3 одного боку, на статистику суттєво впливає порівняно високий рівень самогубств серед засуджених. Тобто у цьому контексті варто відзначити, що все ж не всі смерті пов'язані із недосконалою медичною системою. Проте співвідношення смертей за станом здоров'я до смертей, пов'язаних із самогубством, усе одно свідчить про безсумнівність проблем, спричинених лікуванням ув'язнених, враховуючи те, що поширеними серед них є такі хвороби, як туберкульоз та ВІЛ. Так само проблемним є перебування за гратами засуджених, які мають інвалідність. По-перше, у місцях виконання покарань відсутні будь-які навіть елементарні умови, необхідні для осіб з інвалідністю для того, щоб належним чином забезпечувати свою життєдіяльність. По-друге, як витікає з доповіді, яка аналізується, наявні інші проблеми, такі як забезпечення протезами. Отже, обидві сторони аналізованої проблеми свідчать про складність ситуації із медичним забезпеченням ув'язнених осіб в Україні.

Отже, зробимо висновок про те, що однією з проблем дотримання прав ув'язнених в Україні є проблема медичного забезпечення, яка полягає у такому:

1) високий рівень захворюваності та смертності серед ув'язнених;

2) відсутність належних умов для відбування покарання ув'язненими із інвалідністю;

3) відсутність будь-яких тенденцій та передумов до покращення ситуації із медичним забезпеченням засуджених.

Наступною проблемою, яку відзначають автори доповіді «Дотримання прав ув'язнених в Україні-2016», є невиконання на практиці статті 121 Кримінально-виконавчого кодексу України від 11.07.2003 № 1129-IV [3], яка «звільняє засуджених від сплати за харчування, білизну, одяг та взуття». Зокрема, дослідники вказують на те, що досить тривалий час, незважаючи на наявність цієї норми, по суті, забезпечення зазначених базових потреб ув'язнених не здійснювалось взагалі. На цю проблему протягом тривалого часу вказували громадські активісти, втім вона так і не була вирішена в той спосіб, який пропонувався [2, с. 12]. $\mathrm{У}$ результаті законодавець вирішив ії своєрідно, прийнявши нову редакцію статті 121 Кримінально-виконавчого кодексу України від 11.07.2003 № 1129-IV [3]. Натепер її зміст є таким: «1. Особи, які відбувають покарання у виправних колоніях, відшкодовують витрати на їх утримання, крім вартості харчування, взуття, одягу, білизни, спецхарчування та спецодягу». Це означає, що законодавець вирішив протиріччя між наявною нормою та її виконанням на практиці, i натепер базові потреби засуджених осіб однозначно фінансуються державою, але разом із тим загальне утримання в'язнів здійснюється їхнім коштом. Отже, зробимо висновок про те, що зазначена у доповіді проблема втратила свою актуальність. Законодавець закріпив норму, у якій обов'язок забезпечення базових потреб ув'язнених було однозначно покладено на державу. При цьому ця норма не може тлумачитись неоднозначно.

Іншою проблемою $є$ проблема персоналу установ виконання покарань. 3 одного боку, має місце нестача такого персоналу, з іншого - відчувається вплив його непрофесійного характеру, внаслідок чого відбуваються порушення прав ув'язнених. Так, у доповіді «Дотримання прав ув'язнених в Україні-2016» йдеться про те, що натепер так і невирішена проблема навчання персоналу установ. Спроби владнати це питання мали місце ще у 2012-13 роках шляхом упровадження у систему службової підготовки персоналу навчального курсу «Права людини у пенітенціарній системі», проте будь-яких помітних зрушень у практичній діяльності персоналу та у його ставленні до дотримання прав в'язнів все ще не спостерігається. Ознайомлення персоналу зі стандартами дотримання прав людини все ще залишається поверхневим, адже і сам персонал, і адміністрації установ виконання покарань демонструють байдужість до оволодіння такими знаннями та відсутність волі до правової освіти [2, с. 22]. Як наслідок, і натепер проблема персоналу установ виконання покарань охоплює комплекс проблем, серед яких найгострішою є проблема катувань та жорстокого ставлення до засуджених.

Так само і нині все ще залишаються звичними новини про катування чи побиття засуджених. Керівники в'язничного відомства традиційно заперечують факти катування ув'язнених, але це не означає, що ця проблема вирішена. Наприклад, 13 березня 2019 року моніторингова група відвідала Жовтоводську виправну колонію № 26 внаслідок звернення засуджених про їхне масове побиття групою швидкого реагування. Зі слів засуджених, 6 березня 2019 року в колонії проводився загальний обшук. Близько десятої години ранку на територію установи зайшли озброєні люди в чорних костюмах із закритими балаклавами обличчями. Засуджених почали бити, удари наносили ногами по різних частинах тіла. Переляканим ув'язненим надягли на голову капюшони, змотали скотчем так, щоб закрити очі, в рот засунули ганчірні кляпи, щоб не кричали, 
та відвезли до Криворізької установи виконання покарань № 3 (СI30). Там у такий же спосіб їх викинули з автомобіля, протягли по коридору до камер, при цьому постійно били та ображали. Засудженим не дозволили взяти із собою жодних речей. Тож більшість із них залишилися роздягнуті та босі, оскільки загубили взуття, коли їх тягнули по асфальту. Одинадцять засуджених отримали тілесні ушкодження різного ступеня тяжкості. Так, наприклад, в одного з них було вибито зуб, а в іншого - пошкоджено ребра. Практично всі стверджують, що мали синці та садна на голові, тулубі й на інших частинах тіла, і при цьому за тиждень перебування у CI30 лікарі так і не оглянули засуджених [4]. Наведений приклад є далеко непоодиноким і свідчить про те, що проблеми кваліфікації персоналу установ виконання покарань справді залишаються актуальними, а порушення прав засуджених - поширеними та звичними. Раніше у цій роботі ми звертали увагу на те, що побиття та катування є звичними порушеннями прав засуджених на окупованих територіях Донецької та Луганської областей, втім, як свідчить наше дослідження, схожі проблеми мають місце і на підконтрольній Україні території. Причини, по суті, є тими ж самими - непрофесійність персоналу, для якого права людини є певним абстрактним явищем, що не є фундаментальним для їхньої службової діяльності.

Таким чином, на підставі здійсненого дослідження зробимо висновок, що натепер найгострішими проблемами дотримання прав ув'язнених в Україні є:

1) проблема медичного забезпечення, яка полягає у високому рівні захворюваності та смертності серед ув'язнених та відсутності належних умов для відбування покарання ув'язненими з інвалідністю;

2) проблема ненадання засудженим можливості реалізації свого права на працю у тому обсязі, у якому воно їм гарантоване та забезпечене вітчизняним законодавцем;

3) проблема персоналу установ виконання покарань - його нестачі та непрофесійного характеру, внаслідок чого відбуваються порушення прав ув'язнених у формі катувань, побиття та інших формах.

Загалом, як засвідчило наше дослідження, вирішення наявних проблем дотримання прав ув'язнених неможливе у виключно законодавчий спосіб. Як свідчить досвід нашої держави, внесення змін до чинного Кримінально-виконавчого кодексу України від 11.07.2003 № 1129-IV [3] відбувається регулярно, у тому числі й з приводу сформульованих нами основних проблем. Втім у подальшому такі норми або не знаходять свого застосування на практиці, або призводять до виникнення нових проблем. По суті, зміст кримінально-виконавчого законодавства $€$ таким, за якого адміністрації установ виконання покарань мають можливість використовувати норми чинного законодавства на свою користь і цим регулярно користуються. При цьому заповнення одних прогалин не унеможливлює використання інших.

Так, вирішення проблеми медичного забезпечення засуджених неможливе у виключно законодавчий спосіб. Показники смертності в Україні регулярно перевищують показники народжуваності, і загалом проблема медицини є характерною для всіх верств населення, а не лише засуджених. Окрім того, специфіка установ виконання покарань є сприятливою для розвитку багатьох важких хвороб, таких як туберкульоз чи ВІЛ. Саме тому для вирішення цієї проблеми необхідний комплексний підхід, який включатиме наприклад реформу медицини в нашій державі, переобладнання установ виконання покарань та низку інших заходів, на які нині Україна не має достатніх економічних ресурсів. Те ж стосується і проблем осіб з інвалідністю, які відбувають покарання у вигляді позбавлення волі. Проблема протезування є актуальною не лише для засуджених осіб. Окрім того, вулиці, будівлі, громадський транспорт в Україні не є пристосованими для комфортного існування осіб з інвалідністю. Установи виконання покарання є лише одним з елементів цієї недосконалої системи. I натепер не помітні короткострокові перспективи для вирішення цієї системи на загальнодержавному рівні, а в сфері виконання покарання тим паче.

Проблема ненадання засудженим можливості для реалізації свого права на працю у тому обсязі, у якому воно їм надане вітчизняним законодавцем, є однією з тих, яка була вирішена у законодавчий спосіб шляхом внесення змін до статті 120 Кримінально-виконавчого кодексу України від 11.07.2003 № 1129-IV [3]. Так, беручи до уваги сам зміст норми, можемо зробити висновок про те, що право на працю засуджених усе ж набуло необхідного законодавчого врегулювання, і $€$ натепер саме правом, а не обов'язком засудженого. Втім, варто враховувати те, що згідно зі статтею 121 Кримінально-виконавчого кодексу України від 11.07.2003 № 1129-IV [3], особи, які відбувають покарання у виправних колоніях, відшкодовують витрати на їх утримання. Тобто, хоча засуджених осіб і не примушують працювати, вони вимушені здійснювати це як обов'язок через потребу фінансування свого утримання у місцях виконання покарання. Окрім того, незважаючи на врегулювання державою у частині 1 статті 120 Кримінально-виконавчого кодексу України від 11.07.2003 № 1129-IV [3] питання унормування системи оплати праці, норм праці та розцінок, на практиці у адміністрацій установ виконання все ще залишаються можливості для того, щоб не виконувати ці норми, зокрема у частині ведення обліку відпрацьованого засудженими робочого часу. 
По суті сама адміністрація веде облік, зараховує відпрацьований робочий час засуджених, відповідно до якого відбувається нарахування заробітної платні засудженим. Це залишає простір для маніпуляцій, а також порушень зі сторони адміністрації установ виконання покарань.

Вирішення цієї проблеми є неоднозначним. Враховуючи, що держава натепер не має можливості на належному рівні підтримувати утримання засуджених, варто встановити мінімальну норму праці для засуджених, яка є достатньою для відшкодування витрат на їх утримання. Виконання понаднормової роботи є суб'єктивним правом кожної особи. 3 одного боку, у статті 43 Конституції України [5] встановлено, що використання примусової праці в нашій державі забороняється. Не вважається примусовою працею військова або альтернативна (невійськова) служба, а також робота чи служба, яка виконується особою за вироком чи іншим рішенням суду або відповідно до законів про воєнний і про надзвичайний стан. У таких умовах працю, яка здійснюється засудженими для відшкодування витрат на їхнє утримання можна зарахувати до видів праці, які не є примусовими, хоча, по суті, засуджені вимушені працювати. На нашу думку, в умовах, що склались, працю засуджених варто визначити на конституційному рівні як примусову, адже вони вимушені забезпечувати своє утримування у місцях відбування покарання. Прийняття такої норми, на нашу думку, є малоймовірним, враховуючи процедуру внесення змін до Основного Закону держави, проте це могло би вирішити низку проблем, пов'язаних з утриманням засуджених та забезпеченням їхніх прав. У такому разі Міністерству юстиції України варто було б прийняти спеціальний нормативно-правовий акт, у якому встановити чітку мінімальну норму робочого часу для засуджених, яка би давала змогу забезпечити їх утримання. Це могло би позбавити можливостей зменшувати засудженим норми відпрацьованого часу та недоплачувати їм. При цьому за засудженими варто залишити право працювати понад норму робочого часу за власною ініціативою.

Тож, підсумуємо, що вирішення проблеми ненадання засудженим можливості реалізації свого права на працю у тому обсязі, у якому воно їм надане вітчизняним законодавцем, варто вирішити у такий спосіб:

1) внести зміни до статті 43 Конституції України [5] та сформулювати зміст ії̈ частини 2 таким чином: «Використання примусової праці забороняється. Не вважається примусовою працею військова або альтернативна (невійськова) служба, праця засуджених до позбавлення волі, а також робота чи служба, яка виконується особою за вироком чи іншим рішенням суду або відповідно до законів про воєнний і про надзвичайний стан»;
2) внести зміни до норм Кримінально-виконавчого кодексу України від 11.07.2003 № 1129-IV [3]:

- сформулювати частину 1 статті 118 таким чином: «1. Праця засуджених до позбавлення волі не вважається примусовою у межах відшкодування витрат на їх утримання. Праця здійснюється на добровільній основі на підставі договору цивільно-правового характеру або трудового договору, який укладається між засудженим та фізичною особою-підприємцем або юридичною особою, для яких засуджені здійснюють виконання робіт чи надання послуг»;

- доповнити статтю 118 пунктом 6: «Засуджені можуть залучатись до виконання понаднормових оплачуваних робіт за власною ініціативою»;

- сформулювати частину 1 статті 120 таким чином: «1. Праця осіб, засуджених до позбавлення волі, оплачується відповідно до ії кількості та якості. Форми і системи оплати праці, мінімальні норми праці та розцінки встановлюються нормативно-правовими актами Міністерства юстиції України»;

3) привести у відповідність до зазначених змін Правила внутрішнього розпорядку установ виконання покарань [6].

Остання виділена нами у цій роботі проблема дотримання прав ув'язнених в Україні - проблема персоналу установ виконання покарань, а саме його нестачі та непрофесійного характеру, внаслідок чого відбуваються порушення прав ув'язнених, їх катування чи побиття. Як засвідчило наше дослідження, необхідні законодавчі зміни вже були внесені, проте це у цілому не суттєво вплинуло на вирішення цієї проблеми. На нашу думку, у цьому контексті також необхідний комплексний підхід, який передбачає:

1) підвищення заробітної плати працівникам установ виконання покарань із одночасним підвищенням вимог до їхньої кваліфікації;

2) посилення відповідальності працівників установ виконання покарань за порушення прав засуджених;

3) надання засудженим ширших можливостей щодо захисту ними своїх прав.

Так, підвищення заробітної плати як напрям вирішення наявних проблем має виключно економічний характер і залежить від можливостей держави. Втім, залучення до сфери виконання покарань висококваліфікованих фахівців потребує не лише належного фінансування, але й встановлення більш чітких критеріїв відбору персоналу. Так, згідно із частиною 3 статті 14 Закону України «Про Державну кримінально-виконавчу службу України» від 23.06.2005 № 2713-IV [7], «на службу до Державної кримінально-виконавчої служби України приймаються на конкурсній, добровільній, контрактній основі громадяни України, які спроможні за своїми особистими, діловими та моральними якостями, віком, освітнім і професійним 
рівнем та станом здоров'я ефективно виконувати відповідні службові обов'язки. Кваліфікаційні вимоги до професійної придатності визначаються нормативно-правовими актами Міністерства юстиції України. >..> Не може бути прийнята на службу особа, яка має не погашену або не зняту судимість за скоєння злочину, крім реабілітованої, або на яку протягом останнього року накладалося адміністративне стягнення за вчинення корупційного правопорушення». Так, кваліфікаційні вимоги до персоналу установ виконання покарань є такими: 1) належні особисті, ділові та моральні якості, вік, освітній і професійний рівень та стан здоров'я; 2) відсутність судимості та адміністративних стягнень за вчинення корупційного правопорушення. На нашу думку, цього не досить для прийняття на службу висококваліфікованих фахівців, тому зазначені вимоги варто доповнити обов'язковою наявністю юридичної освіти та проходження спеціальної підготовки.

Окрім того, «ділові та моральні якості» є занадто суб'єктивним критерієм, який не має чітких меж та рамок. Ділові якості визначаються на науковому рівні як здатність знаходити у межах власної компетенції, наданих повноважень та засобів найкращий підхід до ситуацій та найкоротший шлях до досягнення мети, оперативно приймати самостійні обгрунтовані рішення, послідовно забезпечуючи їх виконання [8, с. 37]. Як витікає iз цього визначення, діловими якостями $є$ певна належна особі система навичок та вмінь, яка дає змогу у рамках їі трудової діяльності приймати обгрунтовані, виважені та найбільш правильні рішення. Наявність ділових якостей працівників установ виконання покарань не можна перевірити поза їхньою службовою діяльністю, а лише у тих ситуаціях, які вимагають від них прийняття певних рішень. Будь-яке моделювання ситуацій на стадії підготовки працівників не може точно засвідчити, як поводитиметься працівник тоді, коли буде необхідно прийняти реальне рішення. Тому, на нашу думку, цей критерій оцінювання кандидата на вступ до служби в органах виконання покарання є швидше абстрактним і не дає змогу встановити реальний рівень компетентності працівника.

Моральна якість розглядається як поняття моральної свідомості, за допомогою якого виділяються в суспільному житті і характеризуються з морального погляду найбільш типові риси поведінки людей [9, с. 106]. До моральних якостей варто віднести чесність, порядність, справедливість, доброзичливість, тактовність, доброту, комунікабельність та низку інших чеснот, які, на нашу думку, також не піддаються об’єктивному встановленню. Тобто ділові та моральні якості як критерії відбору працівників кримінально-виконавчої служби, встановлені в нормах Закону України «Про Державну кримінально-виконавчу службу України» від 23.06.2005 № 2713-IV [7], на нашу думку, є тими показниками, які необхідні для працівника кримінально-виконавчої служби і які реально мають бути наявними у висококваліфікованого персоналу, проте не є тими критеріями, які можливо встановити під час прийняття на службу.

У статті 14 Закону України «Про Державну кримінально-виконавчу службу України» від 23.06.2005 № 2713-IV [7] визначено й інші вимоги до кандидатів, які підлягають чіткому встановленню, наприклад «вік, освітній і професійний рівень». Проте в аналізованій нормі не уточнюється взагалі, яким має бути вік кандидата на вступ до кримінально-виконавчої служби та які вимоги висуваються до віку, освіти й професійного рівня таких осіб. Законодавець у цій нормі здійснює посилання на «нормативно-правові акти Mіністерства юстиції України», із чого може скластись враження, що зазначені вище критерії конкретизуються на підзаконному рівні. Серед таких «нормативно-правових актів Міністерства юстиції України» відзначимо Наказ Міністерства юстиції України «Про затвердження Положення про організацію професійної підготовки осіб рядового і начальницького складу Державної кримінально-виконавчої служби України» від 08.09.2015 № 1675/5 [10], втім у його змісті також відсутні чіткі вимоги до працівника установи виконання покарання. Аналізуючи норми цього нормативно-правового акта, варто відзначити, що кожен кандидат на посаду в Державній кримінально-виконавчій службі України проходить спеціальну службову підготовку, у тому числі й фізичну. Отже, можливості для того, щоб встановити «моральні та ділові якості» кандидата наявні, втім, як нами зазначалось раніше, моделювання певних ситуацій не є гарантією реалізації таких навичок у службовій діяльності. Також зі змісту Наказу Міністерства юстиції України «Про затвердження Положення про організацію професійної підготовки осіб рядового і начальницького складу Державної кримінально-виконавчої служби України» від 08.09.2015 № 1675/5 [10] неможливо встановити вимоги до віку кандидата, адже вони відсутні. Із пункту 6 можна зробити висновок, що кандидатами на зайняття вакантної посади в кримінально-виконавчій службі можуть бути як особи віком до 25 років, так і особи, старші 45 років, адже їх у процесі підготовки розподіляють на певні вікові групи. Втім, вікові рамки «до 25» та «від 45» свідчать про те, що будь-які вікові вимоги для кандидатів відсутні. Логічно, що вони мають бути повнолітніми і їхній вік не має бути пенсійним, проте, у контексті законодавчого закріплення має місце прогалина, адже законодавець у Законі України «Про Державну кримінально-виконавчу службу України» від 23.06.2005 № 2713IV [7] встановлює вимогу до віку працівників 
кримінально-виконавчої служби. На нашу думку, такий критерій варто взагалі прибрати із цього законодавчого акта, адже, по суті, він не враховується під час прийняття на службу.

Інші критерії, такі як освітній та професійний рівень, не конкретизовані навіть на підзаконному рівні. Тому вирішення проблеми професійності персоналу установ виконання покарань вбачаємо у законодавчому встановленні конкретних критеріїв відбору персоналу. Особливу увагу, на нашу думку, у контексті забезпечення прав засуджених варто звернути на наявність юридичної освіти у таких осіб та обов'язковість проходження спеціального навчання перед вступом на службу.

Для цього пропонуємо внести зміни до частини 3 статті 14 Закону України «Про Державну кримінально-виконавчу службу України» від 23.06.2005 № 2713-IV [7] та сформулювати її зміст таким чином: «3. На службу до Державної кримінально-виконавчої служби України приймаються на конкурсній, добровільній, контрактній основі громадяни України, які мають вищу юридичну освіту чи пройшли підготовку в спеціалізованих навчальних закладах підготовки кадрів органів та установ виконання покарань, є компетентними, доброчесними, володіють державною мовою та які спроможні за своїми особистими, діловими та моральними якостями, освітнім і професійним рівнем та станом здоров'я ефективно виконувати відповідні службові обов'язки. Кваліфікаційні вимоги до професійної придатності визначаються нормативно-правовими актами Міністерства юстиції України. Під час прийняття на службу може бути встановлений строк випробування до шести місяців. Не може бути прийнята на службу особа, яка має не погашену або не зняту судимість за скоєння злочину, крім реабілітованої, або на яку протягом останнього року накладалося адміністративне стягнення за вчинення корупційного правопорушення» .

Питання стану дотримання прав ув'язнених на тимчасово окупованих територіях Донецької та Луганської областей уже частково нами розглядалось у попередніх підрозділах роботи. Зокрема, серед проблем дотримання прав ув'язнених на тимчасово окупованих територіях Донецької та Луганської областей нами виділялись: 1) залучення ув'язнених до участі у незаконних збройних формуваннях; 2) проблеми забезпечення установ відбування покарань ресурсами; 3) складність переведення засуджених до установ відбування покарань, які розташовані на території, підконтрольній Україні; 4) проблема застосування національного законодавства України.

\section{Jimepamypa}

1. Кримінально-виконавча система України в 2018 році. Статистичний огляд (доповнений). URL: http://ukrprison.org.ua/articles/1551280200 (дата звернення: 14.07.2019).
2. Дотримання прав ув'язнених в Україні-2016. Дванадцята щорічна доповідь "Донецький Меморіал", Київ, 2017, 48 с.

3. Кримінально-виконавчий кодекс України : Закон України від 11.07.2003 № 1129-IV. Відомості Верховної Ради України. 2004. № 3-4, ст. 21.

4. Повернення у минуле, або «Маски-шоу» у виправній колонії: Права Людини в Україні. Інформаційний портал Харківської правозахисної групи. URL: http://khpg.org/index.php?id=1552665703 (дата звернення: 14.07.2019)

5. Конституція України : Закон України від 28.06.1996 р. № 254к/96-ВР. Відомості Верховної Ради України. 1996 р. № 30. Ст. 141.

6. Про затвердження Правил внутрішнього розпорядку установ виконання покарань : Наказ Міністерства юстиції України від 28.08.2018 № 2823/5. Офiиійний вісник України. 2018 р. № 70, с. 285, код акта $91508 / 2018$.

7. Про Державну кримінально-виконавчу службу України : Закон України від 23.06.2005 № 2713-IV. Biдомості Верховної Ради Украӥни. 2005. № 30, ст. 409.

8. Скібіцька Л.І. Організація праці менеджера : навчальний посібник. Київ : Центр учбової літератури, 2010. $360 \mathrm{c.}$

9. Заставнюк О.О. Морально-психологічні якості особистості в структурі професійно-етичної культури менеджера. Вісник національного технічного університету України «Київський політехнічний інститут». Філософія. Психологія. Педагогіка. 07/2009. № 3 ч. 1. С. 104-108.

10. Про затвердження Положення про організацію професійної підготовки осіб рядового і начальницького складу Державної кримінально-виконавчої служби України : Наказ Міністерства юстиції України від 08.09.2015 № 1675/5. Офіиійний вісник України. 2015 р. № 76 , с. 462 , стаття 2546 , код акта $78703 / 2015$.

\section{Анотація}

Квятківський Ю. В. Загальний стан дотримання прав ув'язнених в Україні та стан дотримання прав ув'язнених на тимчасово окупованих територіях Донецької та Луганської областей. - Стаття.

У статті проаналізовано загальний стан дотримання прав ув'язнених в Україні. Досліджено стан дотримання прав ув'язнених на тимчасово окупованих територіях Донецької та Луганської областей. Виявлено перелік особливостей вказаної категорії осіб і охарактеризовано значення кожної з них. Визначено, що проблема медичного забезпечення полягає у такому: високий рівень захворюваності та смертності серед ув'язнених; відсутність належних умов для відбування покарання ув'язненими з інвалідністю; відсутність будь-яких тенденцій та передумов до покращення ситуації із медичним забезпеченням засуджених. 3'ясовано, що не вважається примусовою працею військова або альтернативна (невійськова) служба, а також робота чи служба, яка виконується особою за вироком чи іншим рішенням суду або відповідно до законів про воєнний і про надзвичайний стан. У таких умовах працю, яка здійснюється засудженими для відшкодування витрат на їх утримання, можна зарахувати до видів праці, які не є примусовими, хоча засуджені вимушені працювати. Наголошено, що кваліфікаційними вимогами до персоналу установ виконання покарань є: 1) належні особисті, ділові та моральні якості, вік, освітній і професійний рівень та стан здоров'я; 2) відсутність судимості та адміністративних стягнень за вчинення корупційного правопорушення. Доведено, що проблемами дотримання прав ув'язнених на тимчасово окупованих територіях 
Донецької та Луганської областей залишаються: 1) залучення ув'язнених до участі у незаконних збройних формуваннях; 2) проблеми забезпечення установ відбування покарань ресурсами; 3) складність переведення засуджених до установ відбування покарань, які розташовані на території, підконтрольній Україні; 4) проблема застосування національного законодавства України. Зроблено висновок, що найгострішими проблемами дотримання прав ув'язнених в Україні є: проблема медичного забезпечення, яка полягає у високому рівні захворюваності та смертності серед ув'язнених та відсутності належних умов для відбування покарання ув'язненими з інвалідністю; проблема ненадання засудженим можливості реалізації свого права на працю у тому обсязі, у якому воно їм гарантоване та забезпечене вітчизняним законодавцем; проблема персоналу установ виконання покарань - його нестачі та непрофесійного характеру, внаслідок чого відбуваються порушення прав ув'язнених у формі катувань, побиття та інших формах.

Ключові слова: дотримання прав ув'язнених, законодавче регулювання, виконання покарання, тимчасово окуповані території Донецької та Луганської областей, засуджений.

\section{Summary}

Kviatkivskyi Yu. V. The general state of observance of the rights of prisoners in Ukraine and the state of observance of the rights of prisoners in the temporarily occupied territories of Donetsk and Luhansk regions. Article.

In the article the general state of observance of the rights of prisoners in Ukraine is analyzed. The state of observance of the rights of prisoners in the temporarily occupied territories of Donetsk and Luhansk regions is investigated. The list of features of this category of persons was revealed and the significance of each of them is described. It is determined that the problem of medical care is as follows: high morbidity and mortality among prisoners; lack of proper conditions for serving prison- ers with disabilities; the absence of any tendencies and preconditions for improvement of the situation with the medical provision of convicts. It is established that military or alternative (non-military) service, as well as work or service, which is performed by a person by a sentence or other court decision or in accordance with laws on military and state of emergency, is not considered compulsory labor. In such circumstances, the work carried out by convicts for the reimbursement of expenses for their maintenance can be attributed to types of labor that are not compulsory, although in essence convicts are forced to work. It is stressed that the qualification requirements for personnel of penitentiary institutions are: 1) proper personal, business and moral qualities, age, educational and professional level, and state of health; 2) lack of conviction and administrative penalties for committing a corruption offense. It is proved that the problems of respecting the rights of prisoners in the temporarily occupied territories of Donetsk and Luhansk regions are: 1) the involvement of detainees in participation in illegal armed groups; 2) problems of provision of penal institutions with resources; 3 ) the complexity of the transfer of convicts to institutions of detention, which are located on the territory under the control of Ukraine; 4) the problem of application of the national legislation of Ukraine. It is concluded that the most acute problems of prisoners' rights in Ukraine are: the problem of medical care, which consists of a high level of morbidity and mortality among inmates and the lack of proper conditions for serving prisoners with a disability; the problem of not providing the convicted opportunity to exercise his right to work in the extent to which he is guaranteed and guaranteed by the domestic legislator; the problem of the personnel of penitentiary institutions is its lack of and unprofessional nature, resulting in violations of prisoners' rights in the form of torture, beatings and other forms.

Key words: prisoners rights observance, legislative regulation, execution of punishment, temporarily occupied territories of Donetsk and Luhansk regions, convicted. 